in Europe on ideological lines, led to a split. A number of affiliated organizations withdrew in 1949 and established the ICFTU. The WFTU now draws its membership from the industrially developing countries like India, Vietnam and other Asian countries, Brazil, Peru, Cuba and other Latin American countries, Syria, Lebanon, Kuwait and other Arab countries, and it has affiliates and associates in more than 20 European countries. It has close relations with the International Confederation of Arab Trade Unions, the Organization of African Trade Union Unity as well as the All-China Federation of Trade Unions. The 15th Congress was held in Havana, Cuba in Dec. 2005 and used the slogan 'The working people of the world against globalization and exploitation. For social justice, full employment, solidarity and peace'. Its Trade Unions Internationals (TUIs) have affiliates in Russia, the Czech Republic, Poland and other East European countries, Portugal, France, Spain, Japan and other OECD countries.

The headquarters of the TUIs are situated in Helsinki, New Delhi, Budapest, Mexico, Paris and Moscow. The WFTU and its TUIs have $130 \mathrm{~m}$. members, organized in 92 affiliated or associated national federations and six Trade Unions Internationals, in 130 countries. It has regional offices in Athens, New Delhi, Havana, Dakar, Damascus and Moscow and Permanent Representatives accredited to the UN in New York, Geneva, Paris and Rome.

Headquarters: POB 80, Posta 411, 14200 Prague 4, Czech Republic.

Website: http://www.wftucentral.org

e-mail: info@wftucentral.org

President: Mohammad Assouz (Syria).

General Secretary: George Mavrikos (Greece).

Publications. Flashes From the Trade Unions (fortnightly, published in English, French, Spanish and Arabic), reports of Congresses, etc.

\section{World Wide Fund for Nature (WWF)}

Origin. WWF was officially formed and registered as a charity on 11 Sept. 1961. The first National Appeal was launched in the United Kingdom on 23 Nov. 1961, shortly followed by the United States and Switzerland.

Organization. WWF is the world's largest and most experienced independent conservation organization with over $4.7 \mathrm{~m}$. supporters and a global network of 27 National Organizations, five Associates and 24 Programme Offices.

The National Organizations carry out conservation activities in their own countries and contribute technical expertise and funding to WWF's international conservation programme. The Programme Offices implement WWF's fieldwork, advise national and local governments, and raise public understanding of conservation issues.

Mission. WWF has as its mission preserving genetic, species and ecosystem diversity; ensuring that the use of renewable natural resources is sustainable now and in the longer term, for the benefit of all life on Earth; promoting actions to reduce to a minimum pollution and the wasteful exploitation and consumption of resources and energy. WWF's ultimate goal is to stop, and eventually reverse, the accelerating degradation of our planet's natural environment, and to help build a future in which humans live in harmony with nature.

Address: Avenue du Mont-Blanc, CH-1196 Gland, Switzerland.
Website: http://www.panda.org

Director General: James P. Leape (USA).

President Emeritus: HRH The Prince Philip, Duke of Edinburgh.

President: Chief Emeka Anyaoku (Nigeria).

\section{African Development Bank}

Established in 1964 to promote economic and social development in Africa.

Regional Members. (53) Algeria, Angola, Benin, Botswana, Burkina Faso, Burundi, Cameroon, Cape Verde, Central African Republic, Chad, Comoros, Congo (Dem. Rep. of), Congo (Rep. of), Côte d'Ivoire, Djibouti, Egypt, Equatorial Guinea, Eritrea, Ethiopia, Gabon, The Gambia, Ghana, Guinea, Guinea-Bissau, Kenya, Lesotho, Liberia, Libya, Madagascar, Malawii, Mali, Mauritania, Mauritius, Morocco, Mozambique, Namibia, Niger, Nigeria, Rwanda, São Tomé e Príncipe, Senegal, Seychelles, Sierra Leone, Somalia, South Africa (Rep. of), Sudan, Swaziland, Tanzania, Togo, Tunisia, Uganda, Zambia, Zimbabwe.

Non-regional Members. (24) Argentina, Austria, Belgium, Brazil, Canada, China, Denmark, Finland, France, Germany, India, Italy, Japan, South Korea, Kuwait, Netherlands, Norway, Portugal, Saudi Arabia, Spain, Sweden, Switzerland, UK, USA.

Within the ADB Group is the African Development Fund, established in 1972, which provides development finance on concessional terms to low-income Regional Member Countries which are unable to borrow on the non-concessional terms of the African Development Bank. Membership of the Fund is made up of 25 non-African State Participants, the African Development Bank and the Nigerian Trust Fund.

Official languages: English, French.

Headquarters: 01 BP 1387, Abidjan 01, Côte d'Ivoire.

Website: http://www.afdb.org

e-mail:afdb@afdb.org

President: Donald Kaberuka (Rwanda).

\section{African Export-Import Bank (Afreximbank)}

Established in 1987 under the auspices of the African Development Bank to facilitate, promote and expand intraAfrican and extra-African trade. Membership is made up of three categories of shareholders: Class 'A' Shareholders consisting of African governments, African central banks and sub-regional and regional financial institutions and economic organizations; Class 'B' Shareholders consisting of African public and private financial institutions; and Class ' $\mathrm{C}$ ' Shareholders consisting of international financial institutions, economic organizations and non-African states, banks, financial institutions and public and private investors.

Official languages: English, French, Arabic, Portuguese. Headquarters: World Trade Center, 1191 Corniche El-Nil, Cairo 11221, Egypt.

Website: http://www.afreximbank.com

President and Chairman of the Board: Jean-Louis Ekra (Côte d'Ivoire). 